\title{
早期胃癌の術後再発症例の検討
}

\begin{tabular}{|c|c|c|c|c|c|c|}
\hline \multicolumn{7}{|c|}{ 岐阜市民病院外科 } \\
\hline 大下 & 裕夫 & 田中 & 千凱 & 伊藤 隆夫 & 深田 & 代造 \\
\hline 立花 & 進 & 五島 & 秀行 & 樫塚登美男 & 安藤 & 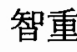 \\
\hline
\end{tabular}

\section{A CLINICAL STUDY ON POSTOPERATIVE RECURRENCE OF EARLY GASTRIC CANCER}

\author{
Hiroo OSHITA, Sengai TANAKA, Takao ITO, \\ Daizo FUKATA, Susumu TACHIBANA, Hideyuki GOSHIMA, \\ Tomio KASHIZUKA and Tomoshige ANDO \\ Department of Surgery, Gifu City Hospital
}

㮂引用語 : early gastric cancer, postoperative recurrence of early sm gastric cancer

はじめに

早期胃癌の予後は進行胃癌に比べて, きわめて良好 であるが，手術時に高度なリンパ節転移，血行性転移， 播種性転移などをさたしている非治搖切除例では，進 行癌と同様に予後不良であることは容易に理解され る. 他方, 治癒切除がなされた早期胃癌でも術後再発 死亡例が報告されている(1)2).

当科でも, 過去 13 年間に 6 例の治㾤切除後再発例を 経験したので，その再発に関する諸因子の検討を行っ た.

\section{対象および方法}

1974年 1 月から1986年12月までの 13 年間に当科で切 除された胃癌は976例で, 胃癌取扱い規約》準じた病 理組織学的検索により, 癌の深達度が $\mathrm{m}, \mathrm{sm}$ の早期胃 癌は271例(27.8\%)であった。これらから多発癌13例， 重複癌13例, 他病死18例, 手術死 4 例, 非治痣切除 5 例を除外した218例についてみると, 深達度 $\mathrm{m}$ (以下 $\mathrm{m}$ 癌之略す) 125 例 (57.3\%), 深達度 $\mathrm{sm}$ (以下 $\mathrm{sm}$ 癌と 略す）93例（42.7\%）であった。このらち術後再発が 6 例 $(2.8 \%)$ 飞認められたが, 癌の深達度はすべて $\mathrm{sm}$ 癌であり, $\mathrm{sm}$ 癌治療切除例の $6.5 \%$ に相当した。早期 胃癌治癒切除218例の遠隔成績は, 5 年生存率 $97.7 \%$, 10 年生存率 $96.8 \%$ であるが, 深達度别にみると, $\mathrm{m}$ 癌 の 5 年, 10 年生存率は $100 \%, \mathrm{sm}$ 癌の 5 年, 10 年生存 率はそれぞれ $94.7 \% ， 92.6 \%$ あった。

$<1989$ 年 6 月 7 日受理 $>$ 別刷請求先 : 大下 裕夫

下500 岐阜市鹿島町 7-1 岐阜市民病院外科
本稿では, 術後再発 6 例の臨床病理像を明らかにし, 早期胃癌の術後再発に関する諸因子の検討を行った。

\section{結 果}

癌の占居部位々再発率との関係は, $\mathrm{A}$ 領域 $10.6 \%$, $\mathrm{M}$ 領域 $2.4 \%$ であり， A 領域の再発率が高かった.

癌の肉眼型では IIa+IIc 混合型の $15.0 \%$, 陥凹型の $5.0 \%$ 再発がみられたが, 隆起型には再発はみられな かった。

癌の最大径と再発との関係をみると, $4.0 \mathrm{~cm}$ 以下の 再発率は $4.3 \%$ あるのに対 し, $4.1 \mathrm{~cm}$ 以上では $12.5 \%$ と高率であった。

原発巣の組織型と再発との関係は, papの再発率が $50.0 \%$ と著しく高率であった。組織型を分化度から分 化型 ( tub $\left._{1}, \mathrm{pap}\right)$, 中分化型 $\left(\mathrm{tub}_{2}\right)$, 未分化型 (por, sig）に分類すると，未分化型には再発が認められない のに対し，分化型では $14.3 \%$ に再発が認められた。

脈管侵襲と再発との関係をみると、リンパ管侵襲陽 性例の再発率は7.5\%であったが, 侵襲程度と再発率と の関係では $\mathrm{l}_{0} 3.8 \%, \mathrm{ly}_{1} 5.8 \%, \mathrm{ly}_{2} 23.0 \%$ ありり, 侵襲程度が進むにつれて再発率む上昇した。一方，静

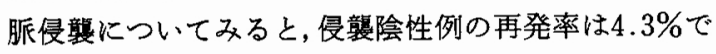
あるのに対し，陽性例では $12.5 \%$ と高率であった。 ま た, A 領域の IIa+IIc 混合型再発例はすべて ly $(+)$, $\mathrm{v}(+)$ であった.

当科での $\mathrm{sm}$ 癌のリンパ節転移率は $22.6 \%$ ある が, リンパ節転移と再発との関係をみると，転移陰性 例の再発率は $4.2 \%$ であるの対し, 転移陽性例では $14.3 \%$ と高率であった。また，第 2 群以遠のリンパ節 
転移例では 3 例中 1 例に再発が認められた。

リンパ節郭清度と再発との関係は, $\mathrm{R}_{2 \sim 3}$ の再発率が $3.7 \%$ であるのに対し， $\mathrm{R}_{1}$ では $25.0 \%$ と高率であった。 術後再発形式は血行性転移 3 例(転移臓器：肝 2 例, 脳 2 例, 肺 1 例), 腹膜再発 1 例, リンパ節再発 1 例, 断端 (残胃) 再発 1 例であった。臨床病理学的因子と 再発形式上の関係をみると，A 領域の IIa + Ilc 混合型 再発例では，高度な脈管侵襲を伴っており，すべて血 行性転移で再発した，癌の大きさや組織型と再発形式 との間には明らかな相関はみられなかった、リンパ節 郭清度と再発形式との関係をみると, $\mathrm{R}_{1}$ 手術例の場 合, $1 \mathrm{y}(+)$ あるいはn $(+)$ 例ではリンパ節再発や腹 膜再発をさたしているのに対し， $\mathrm{R}_{2}$ 手術例では，高度 なリンパ管侵襲やリンパ節転移がみられたものの，す べて静脈侵襲が陽性であり，血行性に再発した。

術後再発例の転帰は 5 例が死亡し，その生存期間は 14〜64か月間，平均32か月間であった。再発生存例は 再発病巣 (脳転移) に対して摘出術が行われ，胃切除 術後30か月間生存している（Table 1).

以下，血行性転移例とリンパ節再発例を供覧する。 症例 $5: 67$ 歳, 男. 血行性転移例.

術前に䲸卵大に腫大した大網リンパ節を触知した。 $\mathrm{CEA}$ は7.8ng $/ \mathrm{ml}$ と高値であった。1984年 9 月 4 日胃 亜全摘術, $\mathrm{R}_{2}$ 郭清を行った. $\mathrm{A}$ 領域, IIa+IIc, $3 \times 2.5$ $\mathrm{cm}$, pap, medullary type, INF $\alpha, \mathrm{ly}_{2}, \mathrm{v}_{1}, \mathrm{n}_{1}$ (3) $1 / 4$, (4) $1 / 4$, 転移率 $2 / 29), \mathrm{P}_{0}, \mathrm{H}_{0}$, stage II であった (Fig. 1, 2). 術後化学療法 (MMC, FT-E, UFT) を 行った.CEA は一過性に低下して正常化したが再上昇 し，1985年 2 月27日に肝転移，10月 3 日に脳転移を確 認した（Fig. 3). 同年11月30日死亡した。

症例 $2: 61$ 歳, 男. リンパ節再発例.

1979年 8 月 1 日胃亜全摘術, $R_{1}$ 郭清を行った。 $A$ 領

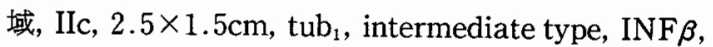
$\mathrm{ly}_{2}, \mathrm{v}_{0}, \mathrm{n}_{0}, \mathrm{P}_{0}, \mathrm{H}_{0}$, stage I であった (Fig. 4, 5). 術後免疫化学療法 (MMC, 5-FU, PSK)を行った。 1980年 3 月 10 日イレウスにて開腹したが, 癌の再発は みられなかった。同年10月 CEA が $13.2 \mathrm{ng} / \mathrm{ml}$ と上昇 し, 腹部腫瘤と左頸部リンパ節腫脹を認めた。同年12 月15日試験開腹術を施行し, 脺と一塊になった示指頭 大〜手拳大のリンパ節を多数認めた。1981年 2 月15日 死亡した（Table 2).

\section{考察}

早期胃癌の再発死亡例は $\mathrm{m}$ 癌では0.4 1.4\% (2)4)5 $^{2}$ と非常に少ないが, sm 癌では5.5〜 5.6\% ${ }^{2 / 4) 5)}$ とかなり
Table 1 Relationship between clinicopathological factors and recurrent rate of sm gastric cancer

\begin{tabular}{|c|c|c|c|}
\hline clinicopathological factor & Whole cases & recurrent cases & recurent rate(\%) \\
\hline location: A & 47 & 5 & 10.6 \\
\hline M & 42 & 1 & 2.4 \\
\hline c & 4 & o & 0.0 \\
\hline gross type : elevated ( I IIIa) & 13 & 0 & 0.0 \\
\hline flat & 0 & 0 & 0.0 \\
\hline depressed( II c. III. Ilc+III) & 60 & 3 & 5.0 \\
\hline $\operatorname{mixed}(I I a+I I c)$ & 20 & 3 & 15.0 \\
\hline \multirow{2}{*}{$\begin{array}{c}\text { size : } 4.0 \mathrm{~cm} \\
4.1 \mathrm{~cm} \\
\end{array}$} & 69 & 3 & 4.3 \\
\hline & 24 & 3. & 12.5 \\
\hline histologic type : tub. & 29 & 2 & 6.9 \\
\hline$t w b=$ & 28 & 1 & 3.6 \\
\hline por & 17 & 0 & 0.0 \\
\hline sig & 12 & 0 & 0.0 \\
\hline pap & 6 & 3 & 50.0 \\
\hline muc & 1 & 0 & 0.0 \\
\hline $\begin{array}{r}\text { Iymphatic invasion: } \operatorname{ly}(-) \\
\operatorname{ly}(+)\end{array}$ & 26 & 1 & 3.8 \\
\hline $\operatorname{ly}(t)$ & 67 & 5 & 7.5 \\
\hline \multirow[t]{2}{*}{ venous invasion } & 69 & 3 & 4.3 \\
\hline & 24 & 3 & 12.5 \\
\hline \multirow{2}{*}{$\begin{array}{r}\text { lymphnpde metastasis : } n(-) \\
n(+)\end{array}$} & 72 & 3 & 4.2 \\
\hline & 21 & 3 & 14.3 \\
\hline \multirow{2}{*}{$\begin{array}{l}\text { lymphnodes dissection : } \mathbf{R} \\
\mathbf{R}_{3 \cdot 3}\end{array}$} & 12 & 3 & 25.0 \\
\hline & 81 & 3 & 3.7 \\
\hline
\end{tabular}

Fig. 1 Gross appearance of the tumor (case 5). Cancer of IIa + IIc mixed type located on antrum.

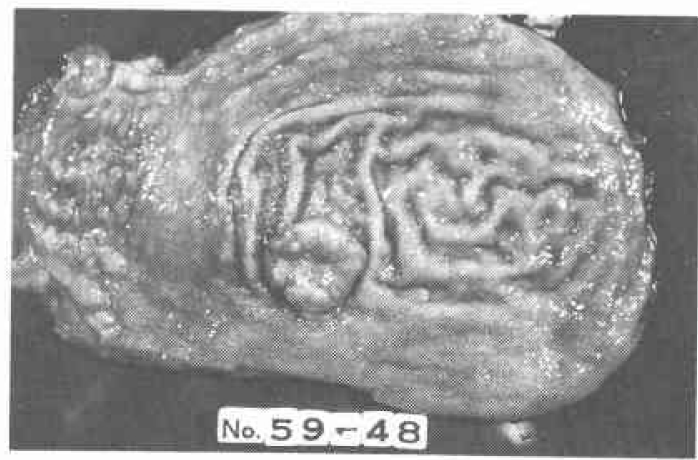

高率である.当科で経験された早期胃癌治癒切除例218 例では, $\mathrm{m}$ 癌の再発はなく, $\mathrm{sm}$ 癌 6 例（早期胃癌の $2.8 \%, \mathrm{sm}$ 癌の $6.5 \%$ )に再発が認められた。以下, こ れら sm 癌再発例の臨床病理学的特徵について考察し た。

$\mathrm{sm}$ 癌の占居部位や肉眼型と術後再発との関係は, 諸家の報告と同様に ${ }^{2) 4}$, 占居部位では $\mathrm{A}$ 領域, 肉眼型 ではIIa+IIc 混合型に高い再発率が認められた。

早期胃癌の大きさと再発死亡率との関連性を指摘す る報告は多く, 細川ら ${ }^{4}$ は $4 \mathrm{~cm}$ 以上と以下での再発率 に差異を認めている，当科での検討でも， $4.0 \mathrm{~cm}$ 以下 では $4.1 \%$ 再発率であるのに対し， $4.1 \mathrm{~cm}$ 以上では 14.3\%と高率であり，両者間に明らかな差異を認めた。

原発单の組織型と術後再発との関連については, 分 化型癌と末分化型癌の再発率に差はないとする報告も 
Fig. 2 Microscopic findings of the tumor (Case 5). papillary adenocarcinoma with invasion of submucosa
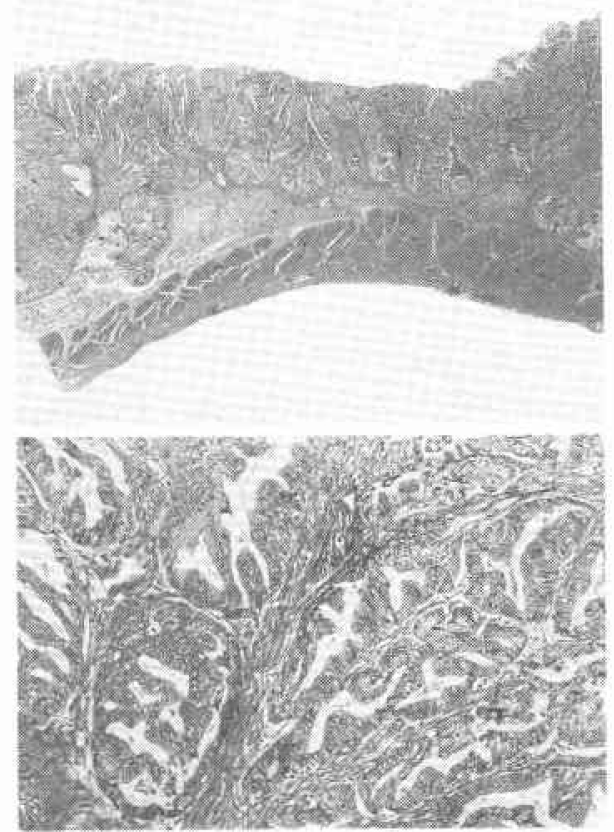

Fig. 3 CT-scan (Case 5): a) liver metastasis (rt-lobe), b) brain metastasis (rt-frontal lobe)

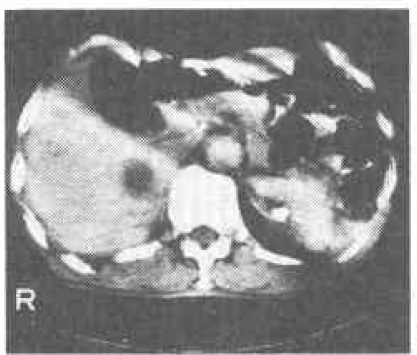

Table 2 Postoperative recurrence of early gastric cancer

\begin{tabular}{|c|c|c|c|c|c|c|c|c|c|c|c|c|c|}
\hline \multirow[b]{2}{*}{ case } & \multirow{2}{*}{ age } & \multirow{2}{*}{ sex } & \multicolumn{3}{|c|}{ gross findings } & \multicolumn{5}{|c|}{ histologic findings } & \multirow{2}{*}{$\begin{array}{l}\text { - intichnodes } \\
\text { dissection }\end{array}$} & \multirow{2}{*}{$\begin{array}{l}\text { survival } \\
\text { interval }\end{array}$} & \multirow{2}{*}{$\begin{array}{l}\text { formation of } \\
\text { recurrence }\end{array}$} \\
\hline & & & location & type $s$ & size(ca) & type & sepoth & iy & v & n & & & \\
\hline I.M. & 73 & maie & A & Ite & 5.3 & pap & $\mathrm{sm}$ & 1\%o & $v_{0}$ & no & $R_{1}$ & 2 Y. 5 M.(dead) & edge \\
\hline G.M. & .61 & male & A & Hle & 2.5 & tub, & sm & $I_{y_{2}}$ & $v_{0}$ & $n_{0}$ & $\mathbf{R}_{1}$ & 1 Y.6M.(dead) & lymphnode \\
\hline T.S. & & temale & A & $11 \mathrm{a}+\mathrm{llc}$ & 2.5 & tub, & $\mathrm{sm}$ & $1 y z$ & v. & $n_{0}$ & $R_{2}$ & 5 Y. $4 \mathrm{M},($ dead $)$ & lung : tiver \\
\hline 10 & 79 & male & M & IIc+1II & 12.0 & pap & $\mathrm{sm}$ & $y$, & $v_{0}$ & $n:$ & $R_{1}$ & 2 Y. 4 M. (dead) & peritoneum \\
\hline 5. & 67 & mate & A & $11 a+11 c$ & 3.0 & pap & $\mathbf{s m}$ & $y_{2}$ & $v_{t}$ & $n$, & $R_{2}$ & 1 Y. $2 \mathrm{M}$.(dead) & brainstiver \\
\hline H.T. & 67 & nale & A & $11 a+13 c$ & 4.5 & $t_{\text {tub }}$ & sm & $i y_{1}$ & $v_{2}$ & $n_{2}$ & $R_{2}$ & $2 Y .6 \mathrm{M}$. (ative) & brain \\
\hline
\end{tabular}

Fig. 4 Gross appearance of the tumor (Case 2). Cancer of IIc type located on anterior wall of antrum.

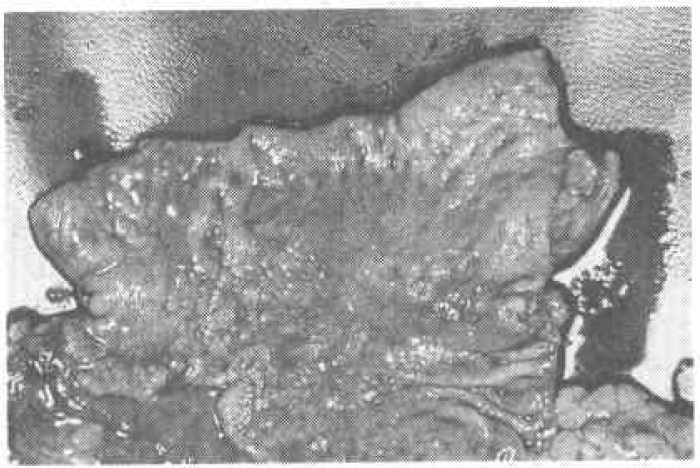

Fig. 5 Microscopic findings of the tumor (Case 2). tubular adenocarcinoma, well differentiated type with invasion of submucosa
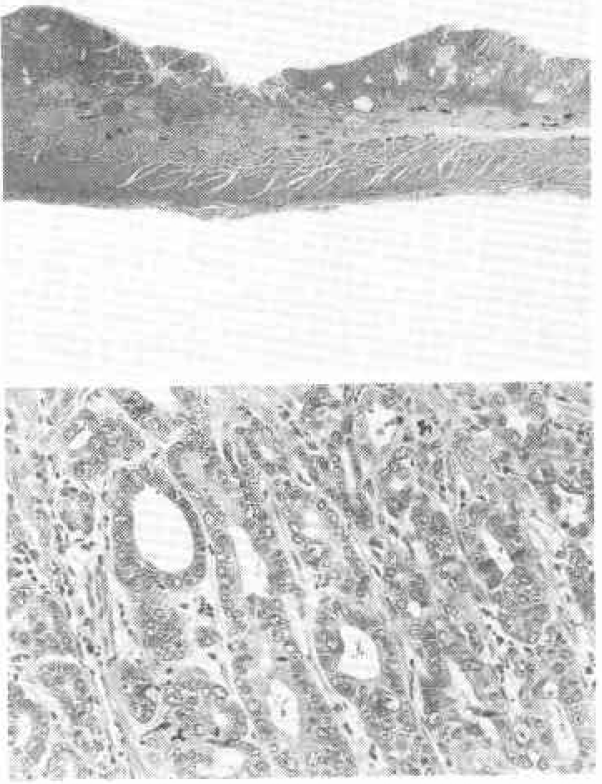

ある ${ }^{4)}$ が，分化度の高い早期胃癌ほど再発率が高いと する報告が多い236). 当科です，porや sigなどの未分化 癌では術後再発がみられないのに対し， tub どの分化癌では14.3\%の再発率が認められて扣り，sm 早期胃癌の分化度と術後再発とは関連性があるものと 思われた。束た，具体的には岸本らうの報告と同様に， papの再発率が $50.0 \%(3 / 6)$ と著しく高率であった。

脈管侵襲は早期胃癌の予後を左右する最む大きな因 
子のひとつであり，侵襲陽性例の再発率は陰性例より も明らかに高く, 予後不良である. 貝原ら 21 は $\mathrm{sm}$ 癌 $\mathrm{ly}$ (+) 症例の再発率を $16.9 \%$, 榊原ら ${ }^{8)}$ は $\mathrm{sm}$ 癌 $\mathrm{v}(+)$ 症例の再発率を $11.8 \%$ と報告している。当科でも，諸 家の報告之同様に，脈管侵襲陽性例の再発率は陰性例 よりも高かったが，とくに， $\mathrm{l}_{2}$ 症例の再発率が著しく 高く, 古賀ら 尚指摘しているように, $\mathrm{ly}_{2}$ 以上のリンパ 管侵襲を早期胃癌の悪性所見のひとつとみなすことが できようまた，A 領域の IIa+IIc 混合型に再発の危 険性が高いとされているが，その理由として，IIa+IIc 混合型では Pen-A 型が多く, 粘膜筋板を全面的に破壊 し，粘膜下層に浸潤して高度な脈管侵襲を伴っている 場合が多い点が指摘されている7).

リンパ節転移の有無も予後を左右する重要な因子で あり，転移陽性例の再発率は高(、1)2101111。 また，リン パ節転移の程度が高度になるにつれて再発率も高くな るとの指摘もある ${ }^{22}$. 当科の検討でも，転移陽性例の再 発率は陰性例よりも高率であり，とくに，第 2 群以遠 のリンパ節転移を認めた症例では 3 例中 1 例 $(33.3 \%)$ が再発した。

早期胃癌の再発形式は腹膜再発が少なく, 肝を中心 とした血行性転移が多い(13)が，再発形式と肉眼型には ある程度の関連性が指摘されている(15)14)15)。すなわ ち, 隆起性ないし混合型 sm 癌で脈管侵襲の著明なむ のは血行性転移が多く, 陥凹型 $\mathrm{sm}$ 癌では腹膜再発を きたしやすい，当科でも IIa +IIc 混合型は高度なりン パ管侵襲と静脈侵襲を伴っておう，血行性転移をきた した。一方, 腹膜再発は IIc + III 陥凹型にみられた。

早期胃癌のリンパ節郭清範囲については, $R_{1}$ と $R_{2}$ 手術の是非に関する議論がいろいるなされているが, $\mathrm{R}_{2}$ のリンパ節郭清を行えば救命しえた可能性のある 症例もいくつか報告されている5111), 当科では, 早期胃 癌に対しても $\mathrm{R}_{2}$ 以上の手術を原則としているが，高 秢, 心肺などの機能低下, 全身状態の不良, $\mathrm{m}$ 癌と判 定しての縮小手術などの理由から，12例 (12.9\%) に $R_{1}$ 手術が施行された. 再発率は $R_{2}$ 以上の手術例では $3.7 \%$ であるのに対し， $\mathrm{R}_{1}$ 手術例では $25.0 \%(3 / 12)$ と 著しく高率であった。この $\mathrm{R}_{1}$ 再発例では 3 例中 2 例 （Case 2，4）はリンパ管侵襲陽性あるいはリンパ節転 移陽性で, リンパ節再発あるいは腹膜再発で死亡して おり， $R_{2}$ 郭清を行えば再発を防止し亲た可能性がある
と思われた。一方， $\mathrm{R}_{2}$ 郭清例では高度なリンパ管侵襲 と静脈侵襲が認められており，十分なリンパ系の郭清 を行ったにもかかわらず，すべて血行性転移をきたし ていることから, 静脈侵襲に対する対策の必要性が痛 感された。

おわりに

早期胃癌の術後再発例について検討した。外科的立 場から早期胃癌の再発を減少させるためには, 術前に 主病巣の形態や深達度を正確に把握したうえで, リン パ管侵襲やリンパ節転移に対しては $\mathrm{R}_{2}$ 郭清, 口側断端 の十分な確保, 静脈侵襲に対しては適切な血行遮断な どの策を講ずるとともに，術後の補助化学療法などの 併用が必要かと思われる。

本論文の要旨は第32回日本消化器外科学会総会（1988年 7 月・金沢）に扔いて発表した。

\section{文献}

1）岩永 剛, 古河 洋, 神前五郎：早期胃癌における 術後再発形式とその問題点. 臨外 $31: 29-35$, 1976

2) 貝原信明, 田村英明, 古賀成昌：早期胃癌術後死亡 原因の分析。胃々腸 $19: 739-743 ， 1984$

3）胃癌研究会編：胃癌取扱い、規約. 改訂第11版, 金原 出版, 東京, 1985

4）細川 治, 山崎 信, 津田昇志汪加: 早期胃癌切除 例1，028例における再発死亡例の検討. 臨外 42： 1983-1986, 1987

5）高木国夫, 太田博俊, 高橋知之泀：外科臨床の立 場からみ心早期胃癌再発死。胃之腸 $19: 773$ $-780,1984$

6）紀藤 毅, 山村義孝: 早期胃癌治療上の問題点. 癌 の臨 $32: 246-249,1986$

7）岩本宏之, 古賀成昌, 井上 淳任か：早期胃癌の再 発. 癌の臨 23: 957-963, 1977

8）榊原宣, 矢端正克, 大村秀俊注か：早期胃癌に拉 ける癌深達度と遠隔成績。臨外 31：15-18, 1976

9）古賀成昌, 岩本宏之, 并上 靖ほか：早期胃癌の術 後成績一相対生存率之術後死亡例の分析一. 外科 治療 36：513-517, 1977

10）広田映五, 海上雅光, 板橋正幸㳗加: 早期胃癌の病 理：病理形態々予後. 消外 $4: 295-300,1981$

11）井上一知, 戸部隆吉：早期胃癌のリン八節転移か らみた術式の選択。消外 9:291一297，1986

12）高木国夫，中田一也：早期胃癌におけるリンパ節 転移と迋隔成績。臨外 $31: 19-27,1976$

13）大森幸夫, 本田一郎：早期胃癌の術後再発一実態 と対策一. 臨外 42:1179-1185，1987

14）井口潔, 杉町圭蔵：早期胃癌の進展之再発形式. 消外 $4: 319-324,1981$

15）吉田弘一, 狩野寛治, 町田哲太ほか：再発症例加ら 々た早期胃癌治療の問題点一臨床病理学的検討 一. 外科 $48: 262-266,1986$ 